\title{
Analysis of Material Deposit on HS6-5-2C Drills Cutting Edges at Processing 42CrMo4 Steel
}

\author{
Valentin DIŢU \\ Transilvania University of Brașov, Romania, vditu@unitbv.ro
}

\begin{abstract}
At reaming processing by drilling, for small and unique series production there are normally used speed steel drills even if the processed material would require metal-carbide drills. This is also the case of 42CrMo4 steel, used also for gear wheels. Being an alloy steel with chromium and molybdenum its processing poses problems. Because the material deposit on the drill's edge has negative consequences, its analysis becomes relevant. The analysis of material deposit is appropriate in order to minimise its negative consequences or to avoid forming it.
\end{abstract}

\section{Keywords}

cutting, drilling, material deposit

\section{Introduction}

The deposit of the processed material on the cutting edge, according to [5], has been reported since the beginning of the systematic study of the metal cutting process (Haussner 1982). The mechanism of forming the deposit on the cutting edge $[2,3,4]$ can be explained on the basis of the existence of the friction between the chip and the face surface of the cutting tool, which determines both temperature in the cutting area and the braking of the chip layer in the immediate vicinity of the face surface. The braked layer has a strongly pressed structure and due to the adhesion forces between the chip and the cutting tool it adheres to the cutting edge. As the hardness of the deposited layer exceeds the hardness of the processed material by $2.5 \div 3.5$ times $[2,3,4,5]$, the deposit forms a new cutting edge (deposit edge) that cuts instead of the cutting edge of the tool (Figure 1). The cutting edge's height increases "H" (Figure 1) and due to the frictional forces and the reaction of the material on the cutting tool, it is quickly destroyed. The phenomenon occurs cyclically and after some research reported in [2] the cyclicity would be $5 \div 50 \mathrm{~Hz}$ and according to the bibliographic source [3] the cyclicity would be greater than $100 \mathrm{~Hz}$.

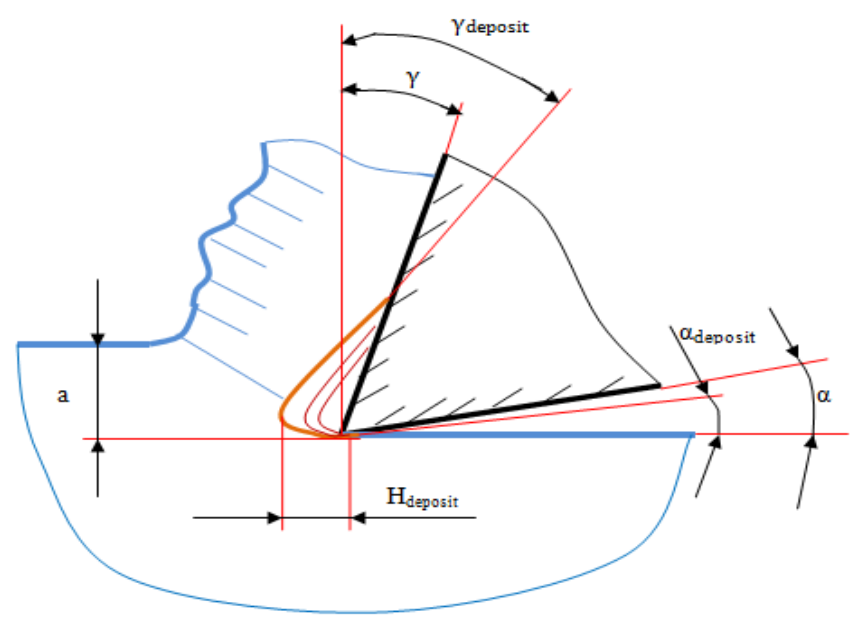

Fig. 1. Material deposit, according to $[2,3,4]$

In Figure 1 there are the next notations: a - thickness of the cutting layer, $\alpha$ - clearance angle, $\gamma$ rake angle, $\mathrm{H}$ - height of material deposit. Also from Figure 1 it can be observed that the material deposit modifies the cutting angles, it raises the rake angle (which is a positive aspect) but it lowers the clearance angle (which is a negative aspect). 
The forming of the material deposit and its dimension depend on:

- the processed material;

- the cutting parameters;

- the cutting tool geometry;

- the used cutting fluid.

The influence of the cutting speed and of the cut layer thickness on the material deposit is shown in Figure 2 (according to [4]).

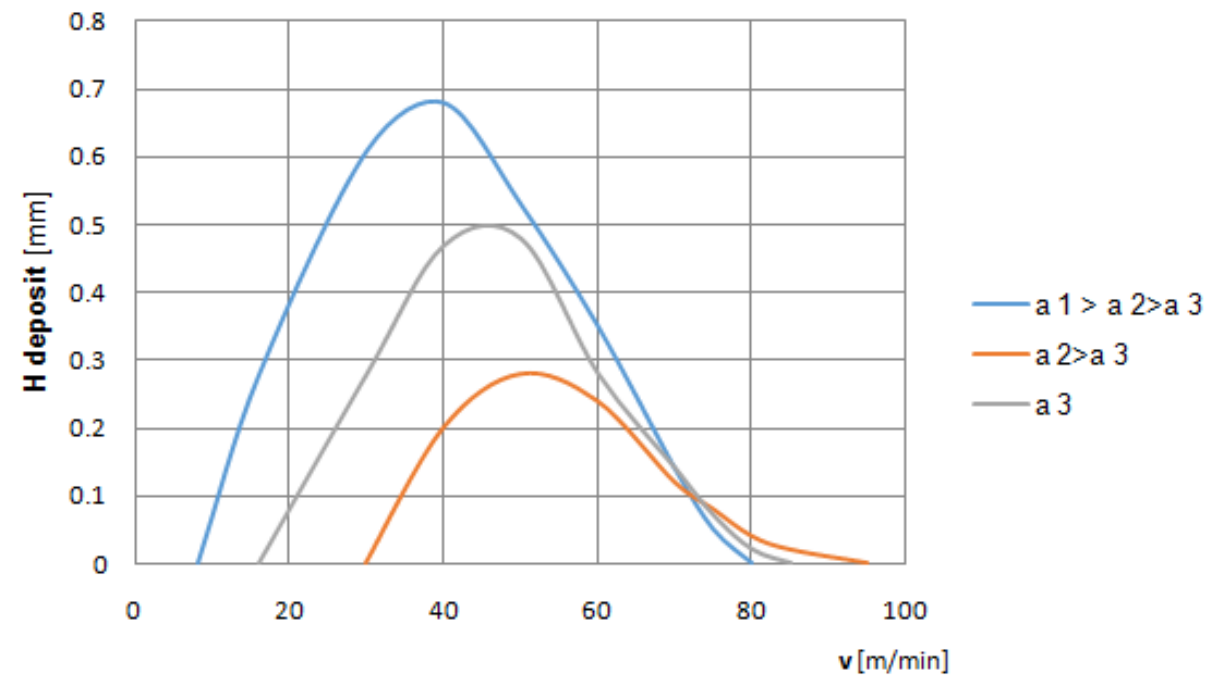

Fig. 2. The influence of the cutting speed and of the cut layer thickness on the material deposit

The consequences of the material deposit are more negative than positive. If in the first phase it protects the cutting edge, the breakage of the deposit leads to the wear of the cutting edge by removing material from it. The cyclical formation of the deposit on the edge determines inconsistency in the roughness of the processed surface and due to the variation of the cutting force, it appear vibrations with negative consequence on the stability of the cutting process.

As can be seen from figure 2, the cutting speed strongly influences the formation of the deposit edge. When cutting ordinary steels (with low carbon content) (Figure 2) the interval of formation of the deposit edge is $10 \div 80 \mathrm{~m} / \mathrm{min}$. The maximum height of the deposit on the edge is about $0.7 \mathrm{~mm}$ and after some sources $[2,4]$ even $0.8 \mathrm{~mm}$.

The processed material influences the deposit on the edge by the degree of plasticity. The higher this is, the higher the deposit height is. The geometry of the cutting tool influences the deposit on the cutting edge especially through the rake angle " $\gamma$ ". After [4], at very large rake angles $\left(\gamma>40^{\circ}\right)$ the deposition on the edge is not formed. But there are very few materials at which the rake angle of the cutting tool is greater than $40^{\circ}$.

The use of cutting fluids is beneficial due to the reduction of the friction between the chip and the rake surface of the cutting tool. The specialty literature offers information about material deposit on the cutting edge, especially for turning and less for other cutting processes (for example drilling, widening). At the same time, there is little information on the formation of the material deposit on the alloy steels that are difficult to process.

Many times, in the production of small and unique series, but also in repairs, we have to process holes in alloyed steel using speed steel drills. Between the processed materials there is also $42 \mathrm{CrMo} 4$ steel.

\section{Experimental Data about Material Deposit at Drilling 42CrMo4 Steel}

To find out to what extent a deposit is formed on the drill cutting edge when processing 42CrMo 4 alloy steel, a batch of 27 HS6-5-2C speed steel drills was taken, each having a diameter of $8 \mathrm{~mm}$. The processed material has the next chemical composition: $\mathrm{C}=0.38 \div 0.45 \%, \mathrm{Si}=0.4 \%$ (maximum), 
$\mathrm{Mn}=0.6 \div 0.9 \%, \mathrm{P}=0.035 \%$ (maximum) $\mathrm{S}=0.030, \mathrm{Cr}=0.9 \div 1.2, \mathrm{Mo}=0.15 \div 0.3$. The tensile strength of $42 \mathrm{CrMo} 4$ steel is $950 \mathrm{MPa}\left(\mathrm{N} / \mathrm{mm}^{2}\right)$ and the hardness is $230 \mathrm{HB}$.

To determinate the optimum cutting parameters it was used the source [6], resulting: $s=14 \mathrm{~m} / \mathrm{min}$, $f=0.25 \mathrm{~mm} / \mathrm{rev}$. The cutting time was five seconds to see whether the formation of the deposit on the edge has a frequency greater than or less than $1 / 5 \mathrm{~Hz}$. The measurement of the deposit was done with Mitutoyo microscope presented in Figure 3, with precision of $1 \mu \mathrm{m}$ and the obtained data are centralized in Table 1.

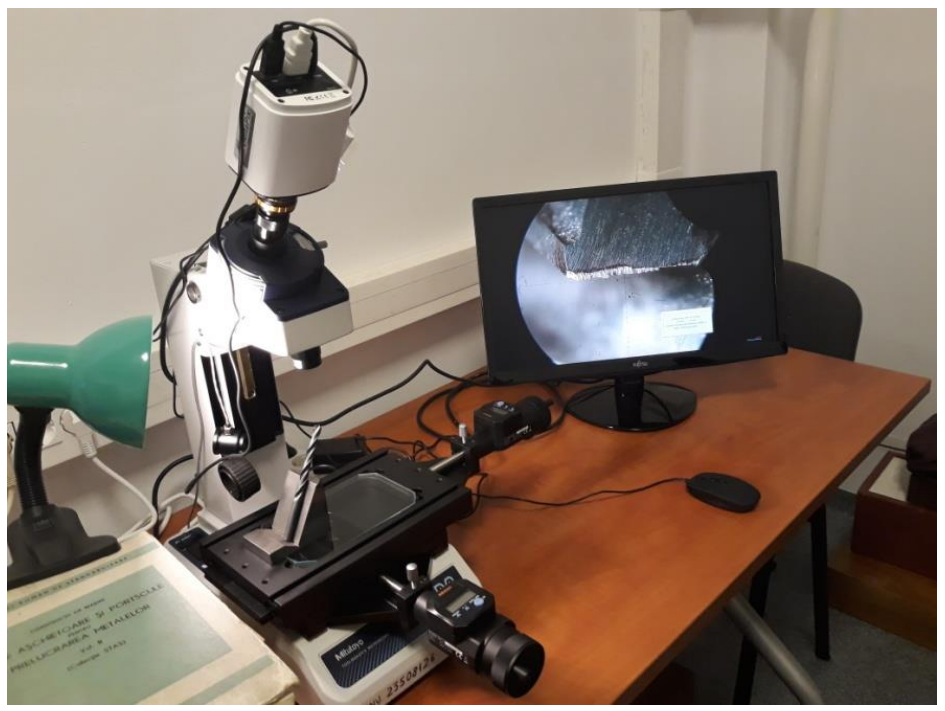

Fig. 3. Microscope for measuring the deposit on edge

The Figure 4 presents the material deposit on the main cutting edge of the drill. It can be observed that it is modifying the rake angle (it is increasing it) and lowers the clearance angle.

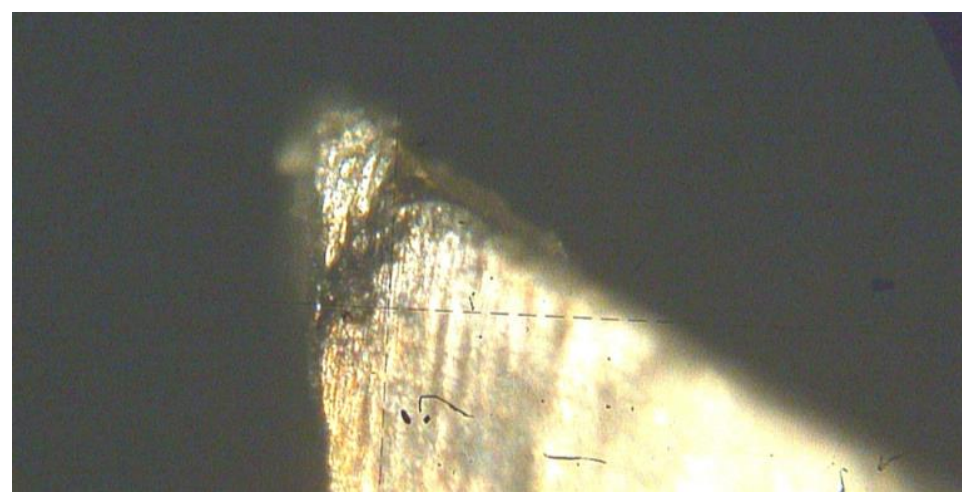

Fig. 4. The material deposit on the drill cutting edge

Analysing data from Table 1 it can be observed:

- all the drills had deposit of material;

- at 12 drills the deposit was formed only on a single edge;

- at 15 drills the deposit was formed on both edges;

- excepting two edges, the deposit was not formed on the entire edge length (Figure 5);

- the minimum diameter for which de deposit was formed is 5,66 mm that corresponds to a cutting speed of $4.68 \mathrm{~m} / \mathrm{min}$ (Figure 6);

- the maximum height of the deposit is $\mathrm{H}_{\max }=0.419 \mathrm{~mm}$ (Figure 7);

- the height of the cutting deposit decreases along the main cutting edge to the minimum diameter which confirms the dependence of the deposit on the cutting speed (Figures 6 and 7). 
RECENT, Vol. 20, no. 1(57), 2019

Table 1. Data about deposits on drills edges

\begin{tabular}{|c|c|c|c|c|c|c|c|}
\hline $\begin{array}{l}\text { No. } \\
\text { of } \\
\text { drill }\end{array}$ & $\begin{array}{l}\text { Diameter } \\
\text { "D" of } \\
\text { drill } \\
\text { [mm] }\end{array}$ & $\begin{array}{c}\text { Placement of } \\
\text { deposit on } \\
\text { edge } 1\left(D_{1}\right) \\
{[\mathrm{mm}]}\end{array}$ & $\begin{array}{l}\text { Length of } \\
\text { deposit } \\
\text { [mm] }\end{array}$ & $\begin{array}{l}\text { Maximum } \\
\text { height "H" } \\
\text { of deposit } \\
{[\mathrm{mm}]}\end{array}$ & $\begin{array}{l}\text { Placement } \\
\text { of deposit } \\
\text { on edge } 2 \\
\left(\mathrm{D}_{2}\right)[\mathrm{mm}]\end{array}$ & $\begin{array}{l}\text { Length of } \\
\text { deposit } \\
\text { [mm] }\end{array}$ & $\begin{array}{l}\text { Maximum } \\
\text { height " } \mathrm{H}_{2} " \\
\text { of deposit } \\
{[\mathrm{mm}]}\end{array}$ \\
\hline 1 & 8 & 0 & 0 & 0 & 8 & 2.452 & 0.271 \\
\hline 2 & 8 & 8 & 2.193 & 0.252 & 0 & 0 & 0 \\
\hline 3 & 8 & 8 & 0.286 & 0.188 & 8 & 2.491 & 0.308 \\
\hline 4 & 8 & $\begin{array}{l}8 \\
2.904\end{array}$ & $\begin{array}{l}0.567 \\
0.8\end{array}$ & 0.219 & 7.415 & 1.983 & 0.223 \\
\hline 5 & 8 & 6.135 & 0.742 & 0.198 & 8 & 1.049 & 0.353 \\
\hline 6 & 8 & $\begin{array}{l}7.105 \\
4.278\end{array}$ & $\begin{array}{l}0.385 \\
0.476\end{array}$ & 0.109 & 8 & 2.457 & 0.228 \\
\hline 7 & 8 & 0 & 0 & 0 & 8 & 1.445 & 0.264 \\
\hline 8 & 8 & 6.730 & 2.709 & 0.253 & 8 & 1.441 & 0.257 \\
\hline 9 & 8 & 0 & 0 & 0 & 8 & 2.793 & 0.267 \\
\hline 10 & 8 & 8 & 1.602 & 0.211 & 5.173 & 0.409 & 0.206 \\
\hline 11 & 8 & 6.620 & 1.474 & 0.216 & 8 & 2.648 & 0.311 \\
\hline 12 & 8 & 0 & 0 & 0 & 8 & 1.372 & 0.296 \\
\hline 13 & 8 & 8 & 0.567 & 0.154 & 8 & 2.670 & 0.251 \\
\hline 14 & 8 & 0 & 0 & 0 & 8 & 0.883 & 0.233 \\
\hline 15 & 8 & 8 & 2.185 & 0.191 & 0 & 0 & 0 \\
\hline 16 & 8 & 8 & 1.986 & 0.346 & 0 & 0 & 0 \\
\hline 17 & 8 & 8 & 1.572 & 0.184 & 0 & 0 & 0 \\
\hline 18 & 8 & 8 & 2.289 & 0.233 & $\begin{array}{l}8 \\
7.191 \\
\end{array}$ & $\begin{array}{l}0.230 \\
0.221 \\
\end{array}$ & 0.161 \\
\hline 19 & 8 & 7.541 & 0.790 & 0.117 & 8 & 0.097 & 0.112 \\
\hline 20 & 8 & 8 & 1.659 & 0.268 & 8 & $\begin{array}{l}\text { On entire } \\
\text { edge }\end{array}$ & 0.176 \\
\hline 21 & 8 & 6,258 & 0.573 & 0.204 & 8 & 2.823 & 0.383 \\
\hline 22 & 8 & 8 & 1.815 & 0.419 & 0 & 0 & 0 \\
\hline 23 & 8 & 8 & 3.083 & 0.245 & 8 & $\begin{array}{l}\text { On entire } \\
\text { edge }\end{array}$ & 0.24 \\
\hline 24 & 8 & 0 & 0 & 0 & 8 & 2.590 & 0.296 \\
\hline 25 & 8 & 8 & 1.983 & 0.309 & 5.298 & 1.896 & 0.231 \\
\hline 26 & 8 & 6.749 & 0.955 & 0.240 & 8 & 1.763 & 0.321 \\
\hline 27 & 8 & 8 & 1.294 & 0.253 & 0 & 0 & 0 \\
\hline
\end{tabular}

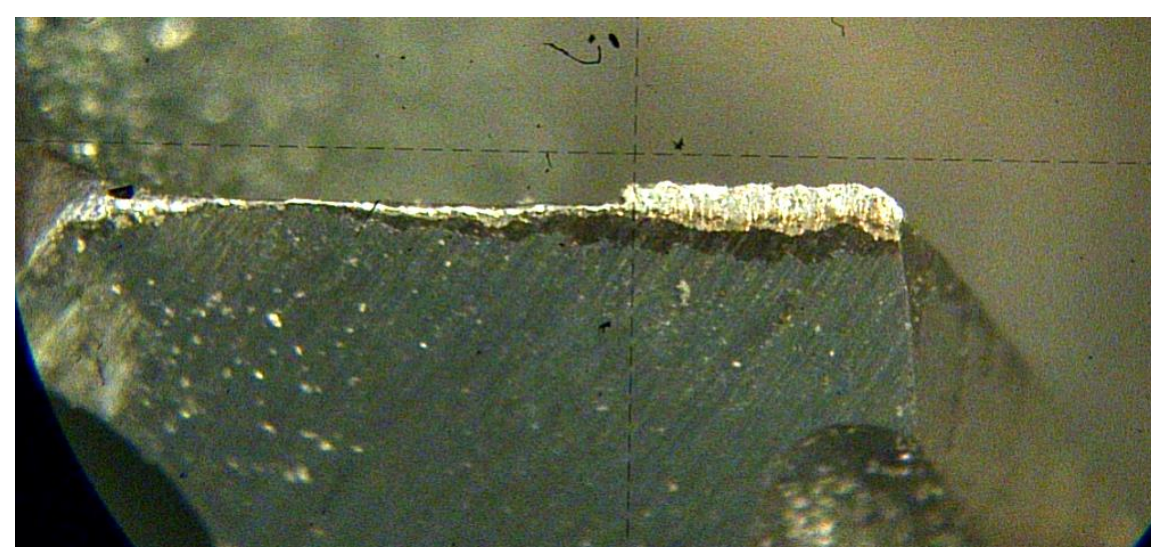

Fig. 5. Material deposit at drill no. 7 


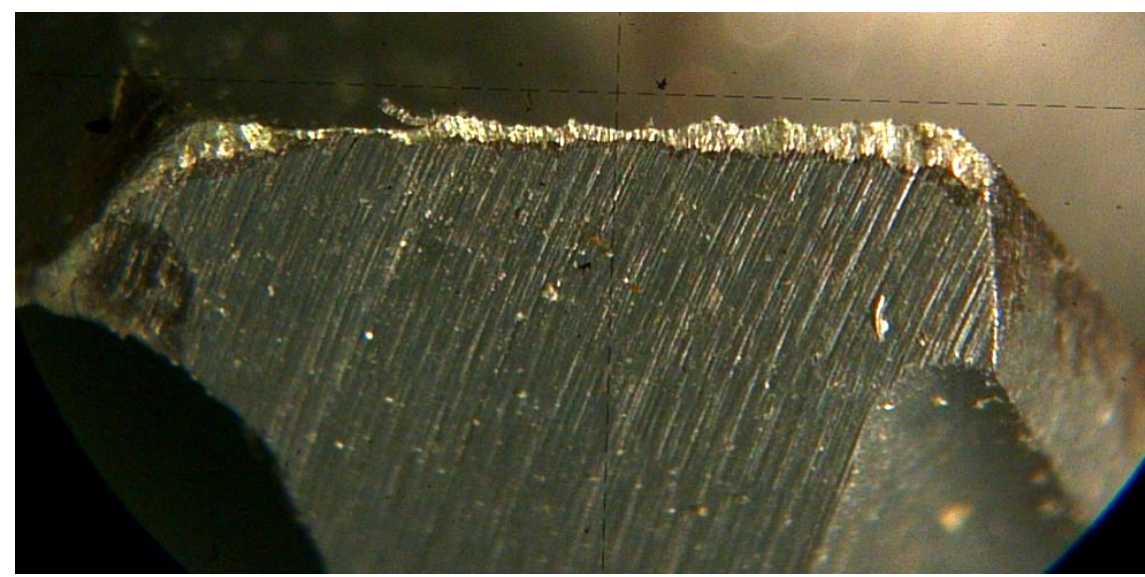

Fig. 6. Minimum diameter where the deposit was formed (at drill no. 23)

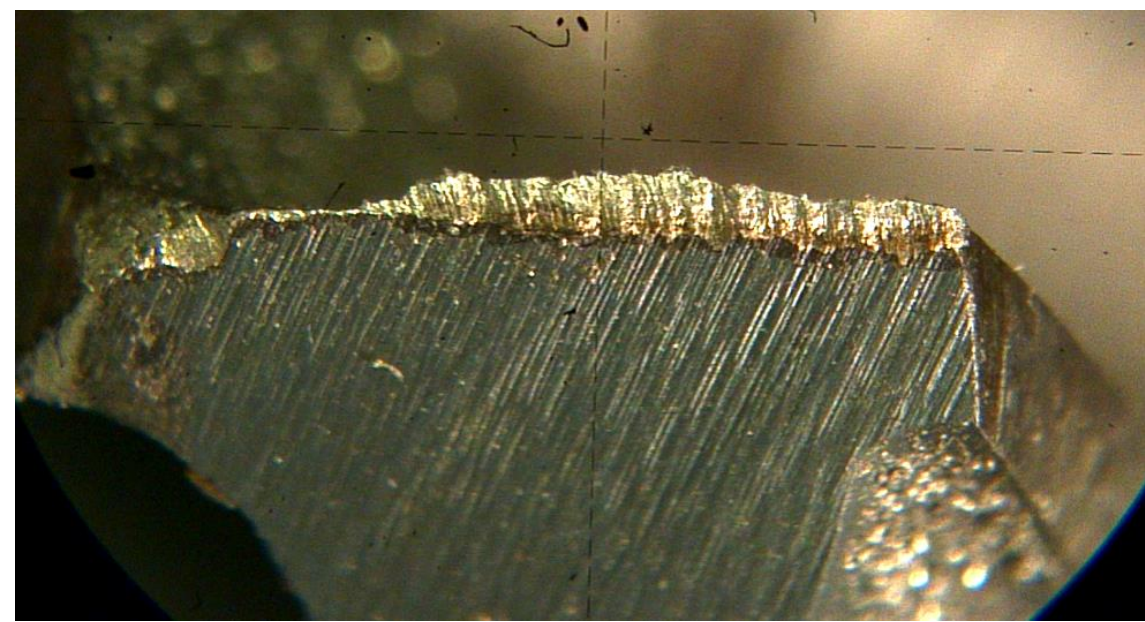

Fig. 7. Maximum height of deposit (at drill no. 22)

In Figure 8 you can see the moment of detachment of the deposit from the edge of the drill. It is noted that this detachment occurred at a maximum deposit height of $0.257 \mathrm{~mm}$.

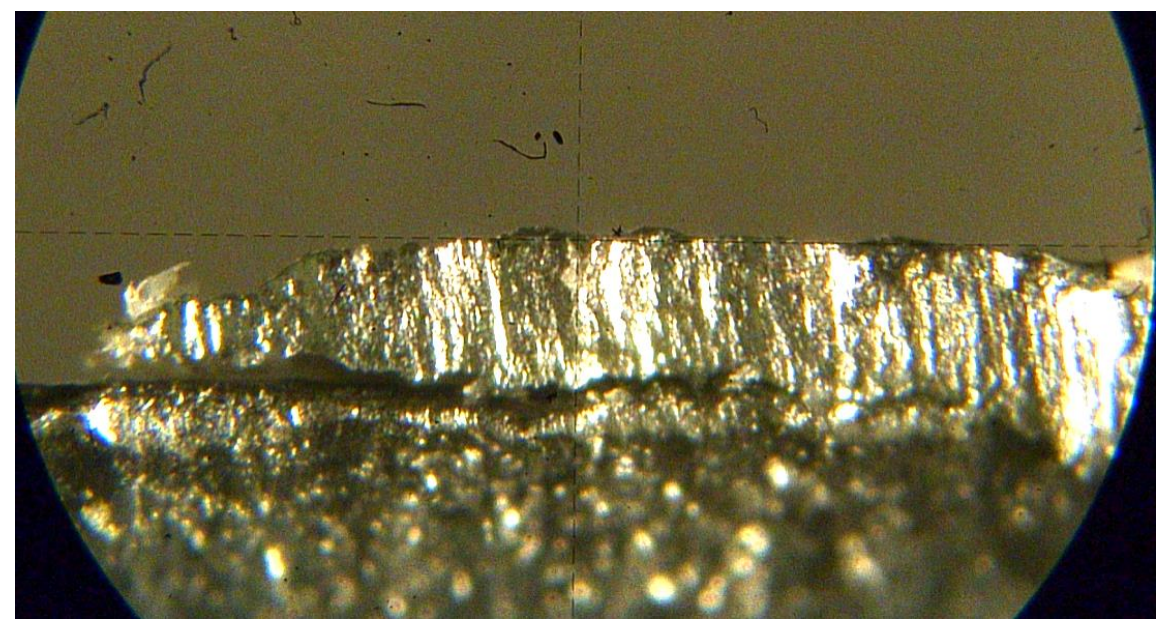

Fig. 8. Detachment of the deposit from the edge (at drill no. 8)

Table 2 shows the maximum height of the material deposit for a drill, regardless of what edge.

Analysing the values from Table 2 it can be observed that the drills can be divided in discrete values of the deposition height (example $\mathrm{H}=0.221 \div 0.280$ ) and in this way, it results data from Table 3 . 
RECENT, Vol. 20, no. 1(57), 2019

Table 2. Maximum height of material deposit for a drill

\begin{tabular}{|c|c|l|l|l|l|l|c|}
\hline $\begin{array}{c}\text { No. } \\
\text { of } \\
\text { drill }\end{array}$ & $\begin{array}{c}\text { Placement of } \\
\text { deposit on } \\
\text { edge 1 or 2 } \\
{[\mathrm{mm}]}\end{array}$ & $\begin{array}{c}\text { Deposit } \\
\text { length } \\
{[\mathrm{mm}]}\end{array}$ & $\begin{array}{c}\text { Maximum } \\
\text { height "H" } \\
\text { of deposit } \\
\text { [mm] }\end{array}$ & $\begin{array}{c}\text { No. of } \\
\text { drill }\end{array}$ & $\begin{array}{c}\text { Placement of } \\
\text { deposit on } \\
\text { edge 1 or 2 } \\
{[\mathrm{mm}]}\end{array}$ & $\begin{array}{c}\text { Deposit } \\
\text { length } \\
\text { [mm] }\end{array}$ & $\begin{array}{c}\text { Maximum } \\
\text { height "H" } \\
\text { of deposit } \\
\text { [mm] }\end{array}$ \\
\hline 1 & 8 & 2.452 & 0.271 & 15 & 8 & 2.185 & 0.191 \\
\hline 2 & 8 & 2.193 & 0.252 & 16 & 8 & 1.986 & 0.346 \\
\hline 3 & 8 & 2.491 & 0.308 & 17 & 8 & 1.572 & 0.184 \\
\hline 4 & 7.415 & 1.983 & 0.223 & 18 & 8 & 2.289 & 0.233 \\
\hline 5 & 8 & 1.049 & 0.353 & 19 & 7.541 & 0.790 & 0.117 \\
\hline 6 & 8 & 2.457 & 0.228 & 20 & 8 & 1.659 & 0.268 \\
\hline 7 & 8 & 1.445 & 0.264 & 21 & 8 & 2.823 & 0.383 \\
\hline 8 & 8 & 1.441 & 0.257 & 22 & 8 & 1.815 & 0.419 \\
\hline 9 & 8 & 2.793 & 0.267 & 23 & 8 & 3.083 & 0.245 \\
\hline 10 & 8 & 1.602 & 0.211 & 24 & 8 & 2.590 & 0.296 \\
\hline 11 & 8 & 2.648 & 0.311 & 25 & 8 & 1.983 & 0.309 \\
\hline 12 & 8 & 1.372 & 0.296 & 26 & 8 & 1.763 & 0.321 \\
\hline 13 & 8 & 2.670 & 0.251 & 27 & 8 & 1.294 & 0.253 \\
\hline 14 & 8 & 0.883 & 0.233 & & & & \\
\hline
\end{tabular}

Table 3. Number of drills for each deposition height category

\begin{tabular}{|c|c|c|c|}
\hline $\begin{array}{c}\text { Deposition } \\
\text { height category }\end{array}$ & $\begin{array}{c}\text { Interval of deposition } \\
\text { height }[\mathrm{mm}]\end{array}$ & $\begin{array}{c}\text { Interval size } \\
{[\mathrm{mm}]}\end{array}$ & $\begin{array}{c}\text { No. of drills from each } \\
\text { category }\end{array}$ \\
\hline 1 & $0.111 \div 0.220$ & 0.11 & 4 \\
\hline 2 & $0.221 \div 0.290$ & 0.07 & 13 \\
\hline 3 & $0.291 \div 0.360$ & 0.07 & 8 \\
\hline 4 & $0.361 \div 0.420$ & 0.06 & 2 \\
\hline
\end{tabular}

In Figure 9 is the graphical representation of data from Table 3.

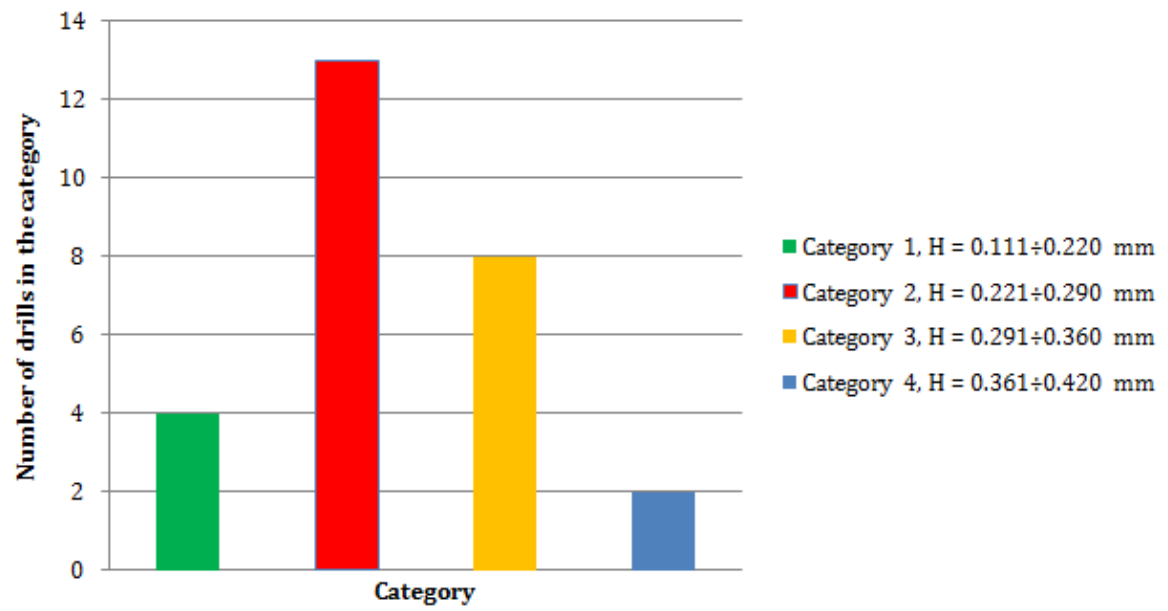

Fig. 9. The graphic of drills division on categories

From Figure 9 it can be seen that 21 drills (most of them) are in categories 2 and 3 . The average of the height deposit of the two categories is $\mathrm{H}_{2,3}$ average $=0.264 \mathrm{~mm}$.

Also, in Figure 10, is captured the inconsistency of the deposit height on the main cutting edge of drill. 


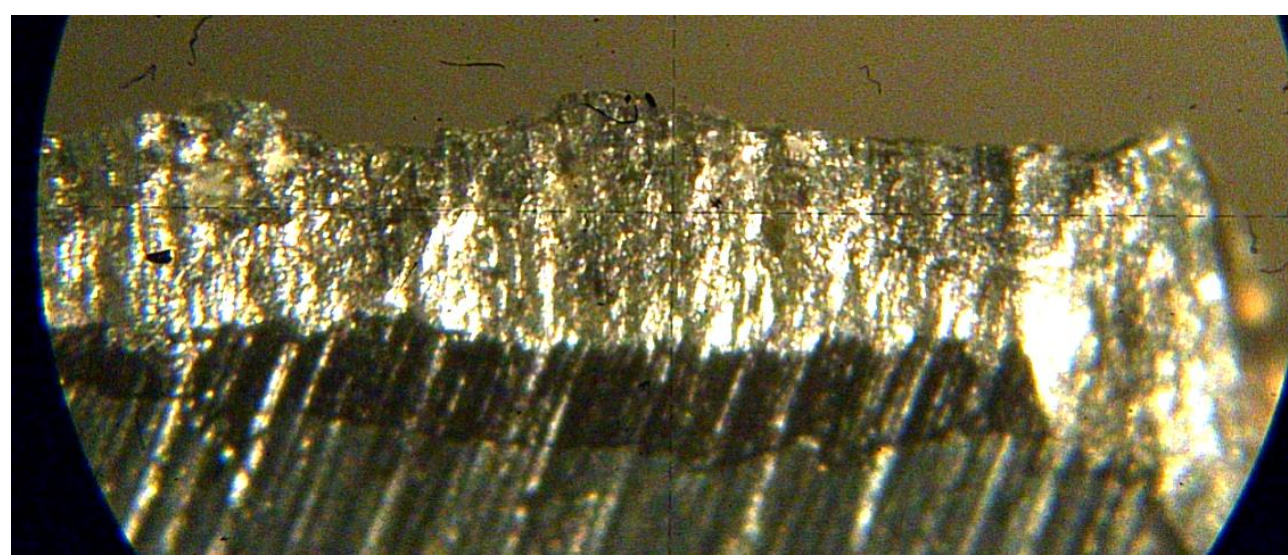

Fig. 10. Irregular material deposit on the cutting edge

\section{Conclusions}

From the followed experiments, the next conclusions can be drawn:

- the material deposit at processing $42 \mathrm{CrMo} 4$ steel with a speed steel drill having the diameter of $8 \mathrm{~mm}$, with optimum cutting parameters, was formed for all the drills used for processing;

- the deposit is inconsistent along the cutting edge;

- the minimum diameter for which the deposit was formed is $5.66 \mathrm{~mm}$ that corresponds to a cutting speed of $4.68 \mathrm{~m} / \mathrm{min}$;

- in a proportion of $78 \%$, the deposit was detached at an average height of $0.264 \mathrm{~mm}$;

- in order to avoid material deposit on the edge, in the analysed case, the cutting speed must be lower than $5 \mathrm{~m} / \mathrm{min}$;

- for drilling 42CrMo4 steel, it would be recommended a metal-carbide drill but also in this case it must be studied if the deposit is formed and which are the optimum cutting parameters.

\section{References}

1. Daicu R., Dițu V. (2016): Innovative analysis of HS 6-5-2 drills edges quality. The 4th International Conference on Computing and Solutions in Manufacturing Engineering 2016 - CoSME'16, MATEC Web Conf., Volume 94, https://doi.org/10.1051/matecconf/20179402004

2. Diţu V. (2008): Bazele așchierii metalelor. Teorie și aplicații (Bases of cutting metals. Theory and applications). MatrixRom, ISBN 978-973-755-444-4, București, Romania (in Romanian)

3. Cordebois J.-P., et al. (2003): Fabrication par usinage (Manufacturing by processing). Dunod, ISBN 2-10005586-0, Paris, France (in French)

4. Fetecău C. (2001): Relații parametrice utilizate la așchiere (Parametric relations when cutting). Editura Tehnică, ISBN 973-31-2020-0, București, Romania (in Romanian)

5. Ștețiu Gr., Lăzărescu I., Oprean C., Ștețiu M. (1994): Teoria și practica sculelor așchietoare (Theory and practice of cutting tools). Vol. I, Editura Universității din Sibiu, ISBN 973-95604-3-1, Sibiu, Romania (in Romanian)

6. Picoș C., et al. (1992): Proiectarea tehnologiilor de prelucrare mecanică prin așchiere (Design of mechanical machining technologies by cutting). Vol. II, Editura Universitas, ISBN 5-362-00971-0, Chișinău, Republic of Moldova (in Romanian) 